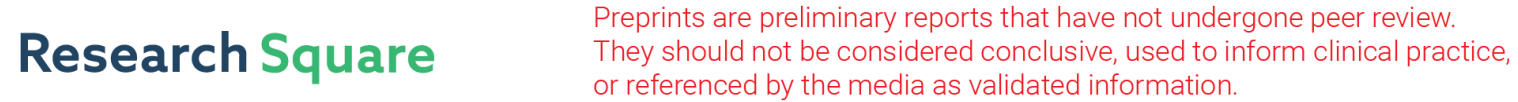 \\ Investigation of Ga Doping for Non-stoichiometric Sodium Bismuth Titanate Ceramics
}

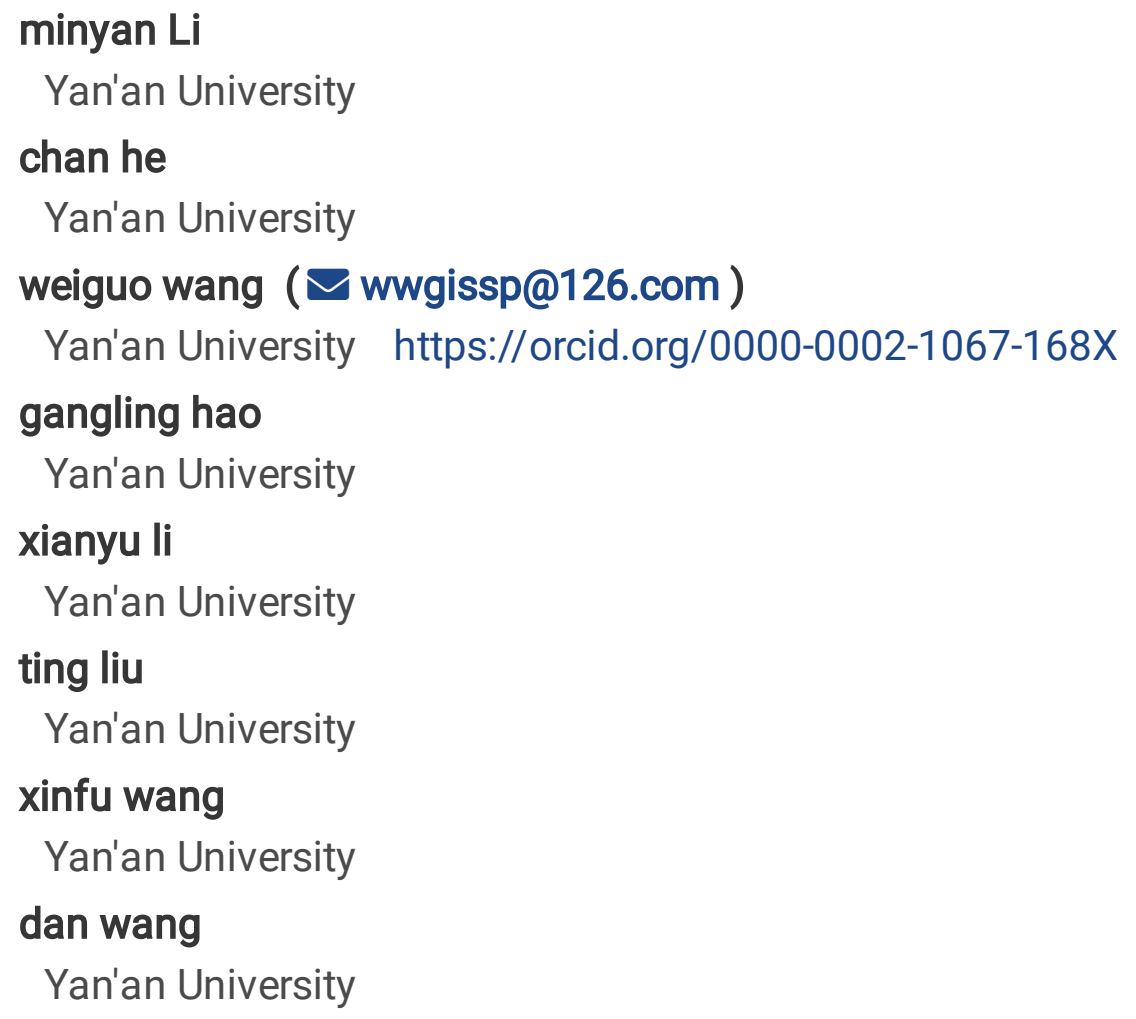

\section{Research Article}

Keywords: oxygen ion conductor, $\mathrm{Na} 0.5 \mathrm{Bi} 0.5 \mathrm{TiO}$, doping, internal friction, vacancy mobility

Posted Date: March 18th, 2021

DOl: https://doi.org/10.21203/rs.3.rs-316726/v1

License: (c) (i) This work is licensed under a Creative Commons Attribution 4.0 International License. Read Full License 


\title{
Investigation of Ga doping for non-stoichiometric sodium bismuth titanate ceramics
}

\author{
M.Y. Li, C. He, W.G. Wang*, G. L. Hao, X.Y. Li, T. Liu, X.F.Wang, D.Wang \\ College of Physics and Electronic Information, Yan'an University, Yan'an 716000, P. \\ R. China
}

\begin{abstract}
The electrical performance of $\mathrm{Ga}^{3+}$ doping $\mathrm{Na}_{0.5} \mathrm{Bi}_{0.5} \mathrm{TiO}_{3}$-based oxygen ion conductor was studied. The $\mathrm{Na}_{0.52} \mathrm{Bi}_{0.47} \mathrm{Ti}_{1-x} \mathrm{Ga}_{\mathrm{x}} \mathrm{O}_{3-\delta} \quad(\mathrm{x}=0,0.01,0.015,0.02)$ samples were fabricated by the means of traditional solid-state reaction. The results of AC impedance measurement show that the bulk conductivity of $\mathrm{Na}_{0.52} \mathrm{Bi}_{0.47} \mathrm{Ti}_{1-\mathrm{x}} \mathrm{Ga}_{\mathrm{x}} \mathrm{O}_{3-\delta}$ samples decrease monotonously with the increase of $\mathrm{Ga}^{3+}$ doping. At $673 \mathrm{~K}$, the bulk conductivity of the $\mathrm{Na}_{0.52} \mathrm{Bi}_{0.47} \mathrm{Ti}_{0.98} \mathrm{Ga}_{0.02} \mathrm{O}_{3-\delta}$ sample is $7.19 \times 10^{-4} \mathrm{~S} / \mathrm{cm}$, which is lower than that of $\mathrm{Na}_{0.52} \mathrm{Bi}_{0.47} \mathrm{TiO}_{3-\delta}$ sample under the identical test temperature. The highest total conductivity emerges in the $\mathrm{Na}_{0.52} \mathrm{Bi}_{0.47} \mathrm{Ti}_{0.99} \mathrm{Ga}_{0.01} \mathrm{O}_{3-\delta}$ sample with $1.387 \times 10^{-4} \mathrm{~S} / \mathrm{cm}$ at $623 \mathrm{~K}$ for the $\mathrm{Ga}^{3+}$ doping content of $1 \mathrm{~mol} \%$, which demonstrate that a slight of $\mathrm{Ga}^{3+}$ doping supports the enhancement of the total conductivity. A relaxation peak was observed in the $\mathrm{Na}_{0.52} \mathrm{Bi}_{0.47} \mathrm{Ti}_{1-\mathrm{x}} \mathrm{Ga}_{\mathrm{x}} \mathrm{O}_{3-\delta}$ compounds. As the $\mathrm{Ga}^{3+}$ ions were introduced into the $\mathrm{Na}_{0.52} \mathrm{Bi}_{0.47} \mathrm{TiO}_{3-\delta}$ compound, there is an increasing trend of the relaxation activation energy educed by the internal friction test. In addition, the oxygen relaxtion height of $\mathrm{Na}_{0.52} \mathrm{Bi}_{0.47} \mathrm{Ti}_{1-\mathrm{x}} \mathrm{Ga}_{\mathrm{x}} \mathrm{O}_{3-\delta}$ samples decreases along with the introduction of the $\mathrm{Ga}^{3+}$ doping, suggesting that the introduction of the $\mathrm{Ga}^{3+}$ leads to the decrease of mobile oxygen vacancy .
\end{abstract}

Keywords: oxygen ion conductor; $\mathrm{Na}_{0 .} \mathrm{Bi}_{0.5} \mathrm{TiO}_{3}$; doping; internal friction; vacancy mobility

\section{Introduction}

Oxygen ion conductors have been quite broadly used, such as oxygen pumps, oxygen separation membranes and solid oxide fuel cells (SOFC), etc.[1-6]. In the past several decades, there are multitudinous research groups devoting to study oxygen ion

\footnotetext{
${ }^{*}$ Corresponding author, Tel: +86-911-2650504; Fax: +86-911-2650504, E-mail: wwgissp@126.com
} 
conductors[1-3]. Recently, $\mathrm{Na}_{0.5} \mathrm{~B}_{\mathrm{i} 0.5} \mathrm{TiO}_{3}$ (NBT), a ferroelectric material with perovskite structure[7,8], can be found that there is a large leakage conductivity. According to the $\mathrm{Li}$ et al. experimental results, the leakage conductivity results from the migration of oxygen defect in the NBT compounds. The oxygen defect mainly comes from the loss of the low melting point elements during preparation $[6,9]$. It is worthy mentioning that the bulk conductivity can reach $1 \times 10^{-2} \mathrm{~S} / \mathrm{cm}$ at the temperature of $873 \mathrm{~K}$ for the $2 \mathrm{~mol} \% \mathrm{Mg}^{2+}$ doped bismuth-deficient NBT compound, $\mathrm{Na}_{0.5} \mathrm{Bi}_{0.49} \mathrm{Ti}_{0.98} \mathrm{Mg}_{0.02} \mathrm{O}_{2.965}[1,7]$. The experimental result offers a new option for exploring intermediate-temperature oxygen ion conductors.

To get the higher electrical properties in the NBT based oxygen ion conductors, higher oxygen vacancy content is necessary. There are two ways to introduce oxygen vacancies into NBT compound: Bi- deficiency and acceptor doping[10]. According to Li Ming et al. results[6], the ionic conductivity can be greatly improved through introducing a low-level non-stoichiometric $\operatorname{defect}(<1$ at.\%) in NBT[1,7]. Especially, the compositions containing Bi-deficent or Na excess exhibit 3-4 orders of mangitude higher than the compositions with Na-defificent or Bi excess[11]. For the other way of introducing oxygen vacancies, it mainly focuses on the acceptor doping of A or B sites. A site acceptor doping are mainly on the trivalent $\mathrm{Bi}^{3+}$ ions replaced by the monovalent ions $\left(\mathrm{Li}^{+}, \mathrm{Na}^{+}, \mathrm{K}^{+}\right)$or divalent ions $\left(\mathrm{Ca}^{2+}, \mathrm{Sr}^{2+}, \mathrm{Ba}^{2+}\right)[1,7,13]$. Yang et al. Reported that $\mathrm{Sr}^{2+}$ doped Bi-deficent NBT-based compounds $\left(\mathrm{Na}_{0.5} \mathrm{Bi}_{0.47} \mathrm{Sr}_{0.02} \mathrm{TiO}_{2.975}\right)$ is a profitable means to improve the electrical properties for oxygen ion conductors[14]. The B-site doping mainly concentrate on low valent ions such as $\mathrm{Mg}^{2+}, \mathrm{Ga}^{3+}$ for $\mathrm{Ti}^{4+}[1-3]$. From the Li et al. experimental results[6], it can be found that the bulk conductivity of the $\mathrm{Mg}^{2+}$ doped bismuth-deficient NBT-based compounds $\left(\mathrm{Na}_{0.5} \mathrm{Bi}_{0.49} \mathrm{Mg}_{0.02} \mathrm{Ti}_{0.98} \mathrm{O}_{2.965}\right)$ which designed by the above two methods is higher than that of the stable $\mathrm{ZrO}_{2}$ doped with $8 \mathrm{~mol} \% \mathrm{Y}_{2} \mathrm{O}_{3}[1,6]$. Xu et al. have investigated that the impact of $\mathrm{K}^{+}$and $\mathrm{Ga}^{3+}$ co-doped on the electric properties of NBT based oxygen ion conductor[2]. In our previous work, we have introduced excess $\mathrm{Na}^{+}$in NBT-based oxygen ion conductor, the bulk conductivity of $\mathrm{Na}_{0.54} \mathrm{Bi}_{0.46} \mathrm{TiO}_{2.96}$ is $1.6 \times 10^{-3} \mathrm{~S} / \mathrm{cm}$ at $673 \mathrm{~K}[15]$. Considering that the ionic radius of 
$\mathrm{Ga}^{3+}(0.062 \mathrm{~nm})$ is very close to that of $\mathrm{Ti}^{4+}(0.061 \mathrm{~nm})$ leading to a small elastic strain energy which is beneficial to the formation of stable solid solution[1-2], $\mathrm{Ga}^{3+}$ ion was selected as a acceptor ion to substitute the $\mathrm{B}$-site $\mathrm{Ti}^{4+}$ ions included the Bi-deficent $\mathrm{Na}_{0.52} \mathrm{Bi}_{0.47} \mathrm{TiO}_{3-\delta}$ compound to gain the higher electrical properties of NBT oxygen ion conductors. The phase structure, electrical properties and diffusion of oxygen ions were studied by X-ray diffractometer, impedance spectrum and internal friction spectrum respectively.

\section{Experimental procedure}

The $\mathrm{Na}_{0.52} \mathrm{Bi}_{0.47} \mathrm{Ti}_{1-\mathrm{x}} \mathrm{Ga}_{\mathrm{x}} \mathrm{O}_{3-\delta}$ compounds $(\mathrm{x}=0,0.01,0.015,0.02)$ were elaborated by conventional solid phase reaction method using high purity $\mathrm{Na}_{2} \mathrm{CO}_{3}, \mathrm{Bi}_{2} \mathrm{O}_{3}, \mathrm{TiO}_{2}$ and $\mathrm{Ga}_{2} \mathrm{O}_{3}$ [13]. In order to eliminate absorbed water and $\mathrm{CO}_{2}$, the raw materials mentioned above were dried at $573 \mathrm{~K}$ for around $12 \mathrm{~h}$. The detailed preparation procedure can be seen in Ref. [12]. The initial reactive $\mathrm{Na}_{0.52} \mathrm{Bi}_{0.47} \mathrm{Ti}_{1-\mathrm{x}} \mathrm{Ga}_{\mathrm{x}} \mathrm{O}_{3-\delta}$ powders were compacted into the cylindrical and bar samples, then the compacted samples were sintered at $1323 \mathrm{~K}$ for $12 \mathrm{~h}$ with the same compositions $\mathrm{Na}_{0.52} \mathrm{Bi}_{0.47} \mathrm{Ti}_{1-\mathrm{x}} \mathrm{Ga}_{\mathrm{x}} \mathrm{O}_{3-\mathrm{x}}$ powder embedded around them.

The phase structure of $\mathrm{Na}_{0.52} \mathrm{Bi}_{0.47} \mathrm{Ti}_{1-\mathrm{x}} \mathrm{Ga}_{\mathrm{x}} \mathrm{O}_{3-\delta}$ samples was detected by a laboratory X-ray diffractometer (Japanese Science Ultima IV diffractometer ) using $\mathrm{CuK} \alpha$ incident radiation in the range of $10^{\circ} \leq 2 \theta \leq 80^{\circ}$. The conductive silver paste was well-distributed applied on the upper and lower surfaces of the cylinder sample and baked at $973 \mathrm{~K}$ for $2 \mathrm{~h}$ to serve as an electrode. In order to study the electrical performance of the samples, the impedance spectroscopy technique was applied using Impedance Analyzer instrument (Instrument type: IM 3536, 10-8 MHz) with a frequency range of $1 \mathrm{~Hz}$ to $1 \mathrm{MHz}$ from $473 \mathrm{~K}$ to $723 \mathrm{~K}$. The low- frequency internal friction (IF) spectroscopy were performed on a inverted torsion pendulum in the form of forced vibration controlled by a computer.

\section{Experimental results}

\subsection{Phase structure}

Figure 1 shows the XRD patterns of $\mathrm{Na}_{0.5} \mathrm{Bi}_{0.5} \mathrm{TiO}_{3}$ and $\mathrm{Na}_{0.52} \mathrm{Bi}_{0.47} \mathrm{Ti}_{1-\mathrm{x}} \mathrm{Ga}_{\mathrm{x}} \mathrm{O}_{3-\delta}$ $(x=0,0.01,0.015,0.02)$ samples. There were no extra peaks of impurity phase in the 
compositions of $\mathrm{Na}^{+}$excess and $\mathrm{Ga}^{3+}$ doped NBT samples through comparing the diffraction pattern with $\mathrm{Na}_{0.5} \mathrm{Bi}_{0.5} \mathrm{TiO}_{3}$ compound, which suggested that excess $\mathrm{Na}^{+}$ and $\mathrm{Ga}^{3+}$ ions are dissolved into the perovskite lattice of NBT-based compounds[13]. According to Scherrer equation: $D=\mathrm{K} \lambda / \beta \cos \theta$, where $D$ is the grain sizes, $\mathrm{K}$ is the Scherrer constant (generally 0.89), $\beta$ is the full width at half maximum (FWHM) of the diffraction peak, and $2 \theta$ is the diffraction angle, the grain sizes is inversely proportional to the FWHM[3]. From the XRD patterns of $\mathrm{Na}_{0.52} \mathrm{Bi}_{0.47} \mathrm{Ti}_{1-\mathrm{x}} \mathrm{Ga}_{\mathrm{x}} \mathrm{O}_{3-\delta}$ samples, it can be obtained that the FWHM of the the diffraction peak $\left(2 \theta=32.8^{\circ}\right)$ for $\mathrm{Na}_{0.52} \mathrm{Bi}_{0.47} \mathrm{Ti}_{1-\mathrm{x}} \mathrm{Ga}_{\mathrm{x}} \mathrm{O}_{3-\delta}(\mathrm{x}=0,0.01,0.015,0.02)$ samples are $0.366^{\circ}, 0.481^{\circ}, 0.387^{\circ}$ and $0.369^{\circ}$, respectively. Thus, it can be deduced that the grain size of $\mathrm{Na}_{0.52} \mathrm{Bi}_{0.47} \mathrm{Ti}_{0.99} \mathrm{Ga}_{0.01} \mathrm{O}_{3-\delta}(\mathrm{x}=0.01)$ sample is smallest.

For perovskite structure materials, Goldschmidt tolerance factor $\mathrm{t}$ is of great significance to the structural stability and properties[17]. By the definition of the Goldschmidt tolerance factor, The tolerance factor of the $\mathrm{Na}_{0.52} \mathrm{Bi}_{0.47} \mathrm{Ga}_{\mathrm{x}} \mathrm{Ti}_{1-\mathrm{x}} \mathrm{O}_{3-\delta}(\mathrm{x}=0$, $0.01,0.015,0.02)$ samples are $0.97662,0.97658,0.97654$ and 0.97652 , separately. The tolerance factor for the $\mathrm{Na}_{0.52} \mathrm{Bi}_{0.47} \mathrm{Ti}_{1-\mathrm{x}} \mathrm{Ga}_{\mathrm{x}} \mathrm{O}_{3-\delta}(\mathrm{x}=0,0.01,0.015,0.02)$ samples was virtually unchanged, which indicates that $\mathrm{Ga}^{3+}$ doping has very little effects on the lattice distortion.

\subsection{Ionic conductivity}

Figure 2 represents the complex impedance spectra for the $\mathrm{Na}_{0.52} \mathrm{Bi}_{0.47} \mathrm{Ti}_{1-\mathrm{x}} \mathrm{Ga}_{\mathrm{x}} \mathrm{O}_{3-\delta}(\mathrm{x}=0,0.01,0.015)$ samples at $643 \mathrm{~K}$. Considering the image recognition, the plot of the $\mathrm{Na}_{0.52} \mathrm{Bi}_{0.47} \mathrm{Ti}_{0.98} \mathrm{Ga}_{0.02} \mathrm{O}_{3-\delta}$ sample is not given. The complex impedance spectra of the $\mathrm{Na}_{0.52} \mathrm{Bi}_{0.47} \mathrm{Ti}_{1-\mathrm{x}} \mathrm{Ga}_{\mathrm{x}} \mathrm{O}_{3-\delta}$ samples all contain three depressed semicircles, in which the semicircles at high frequency and low frequency correspond to grain polarization and electrode polarization response. And the depressed semicircles locating at the intermediate-frequency range can be ascribed to the grain boundary response[18]. An equivalent circuit formed by three R//CPE elements in series is used to fit the impedance spectrum[16,19]. The curve-fitting results are presented in the table 1. The capacitance at high frequency and low 
frequency is about $10^{-10} \mathrm{~F}$ and $10^{-7} \mathrm{~F}$, which is the typical grain response and electrode response of oxygen ion conductor[12,13,19].

The conductivity of $\mathrm{Na}_{0.52} \mathrm{Bi}_{0.47} \mathrm{Ti}_{1-x} \mathrm{Ga}_{\mathrm{x}} \mathrm{O}_{3-\mathrm{x}}(\mathrm{x}=0,0.01,0.015,0.02)$ samples can be obtained by the formula $\sigma=\mathrm{L} /(\mathrm{SR})$, in which $\mathrm{L}$ and $\mathrm{S}$ refer to the bottom area and the thickness of cylinder sample, respectively. The bulk conductivity and total conductivity can be calculate by $\sigma_{b}=L /\left(\mathrm{SR}_{b}\right)$ and $\sigma_{t}=L /\left(\mathrm{SR}_{\mathrm{t}}\right)$, where $\mathrm{R}_{\mathrm{t}}$ is the total resistance of the sum of grain resistance and grain boundary resistance[3,19]. Figure 3 exhibits the Arrhenius plots of the bulk conductivity for the $\mathrm{Na}_{0.52} \mathrm{Bi}_{0.47} \mathrm{Ti}_{1-\mathrm{x}} \mathrm{Ga}_{\mathrm{x}} \mathrm{O}_{3-\delta}$ samples $(x=0,0.01,0.015,0.02)[15]$. Because the conductivity of the $\mathrm{Na}_{0.52} \mathrm{Bi}_{0.47} \mathrm{Ti}_{1-\mathrm{x}} \mathrm{Ga}_{\mathrm{x}} \mathrm{O}_{3-\delta}(\mathrm{x}=0,0.01,0.015,0.02)$ samples is very close, it's hard to distinguish them apart. Thus figure 4 exhibits the bulk conductivity of $\mathrm{Na}_{0.52} \mathrm{Bi}_{0.47} \mathrm{Ti}_{1-x} \mathrm{Ga}_{\mathrm{x}} \mathrm{O}_{3-\delta}$ samples dependent the $\mathrm{Ga}^{3+}$ doping content. Unlike other doped elements, the bulk conductivity of the $\mathrm{Na}_{0.52} \mathrm{Bi}_{0.47} \mathrm{Ti}_{1-\mathrm{x}} \mathrm{Ga}_{\mathrm{x}} \mathrm{O}_{3-\delta}(\mathrm{x}=0,0.01,0.015$, 0.02) samples presents a monotonous reduction with the increase of $\mathrm{Ga}^{3+}$ concentration[1]. When the $\mathrm{Ga}^{3+}$ doped content increases from $1 \mathrm{~mol} \%$ to $2 \mathrm{~mol} \%$, the bulk conductivity decreases from $1.01 \times 10^{-3} \mathrm{~S} / \mathrm{cm}$ to $7.19 \times 10^{-4} \mathrm{~S} / \mathrm{cm}$ at $673 \mathrm{~K}$.

Figure 5 gives the total conductivity of the $\mathrm{Na}_{0.52} \mathrm{Bi}_{0.47} \mathrm{Ti}_{1-\mathrm{x}} \mathrm{Ga}_{\mathrm{x}} \mathrm{O}_{3-\mathrm{x}}$ samples dependent the $\mathrm{Ga}^{3+}$ doping content at the different measuring temperature[13,15]. With introducing $\mathrm{Ga}^{3+}$ into the $\mathrm{Na}_{0.52} \mathrm{Bi}_{0.47} \mathrm{Ti}_{1-\mathrm{x}} \mathrm{Ga}_{\mathrm{x}} \mathrm{O}_{3-\mathrm{x}}$ samples, the total conductivity shows a tendency to increase first and then decrease. When $1 \mathrm{~mol}^{\circ} \mathrm{Ga}^{3+}$ is introduced, the highest total conductivity can be obtained with $1.387 \times 10^{-4} \mathrm{~S} / \mathrm{cm}$ at $623 \mathrm{~K}$, suggesting that a slight of $\mathrm{Ga}^{3+}$ doping can enhance the total conductivity of the $\mathrm{Na}_{0.52} \mathrm{Bi}_{0.47} \mathrm{Ti}_{1-\mathrm{x}} \mathrm{Ga}_{\mathrm{x}} \mathrm{O}_{3-\mathrm{x}}$ compounds[1]. From the analyzed results of XRD curves, there is the smaller grain size of the $\mathrm{Na}_{0.52} \mathrm{Bi}_{0.47} \mathrm{Ti}_{0.99} \mathrm{Ga}_{0.01} \mathrm{O}_{3-\delta}(x=0.01)$ sample. The smaller grain size causes the larger grain boundary volume and lower impurity density in the grain boundary of the $\mathrm{Na}_{0.52} \mathrm{Bi}_{0.47} \mathrm{Ti}_{0.99} \mathrm{Ga}_{0.01} \mathrm{O}_{3-\delta}(\mathrm{x}=0.01)$ sample, which results in the lower grain boundary resistence and higher grain boundary conductivity[3]. Therefore, the grain boundary conductivity in $\mathrm{Na}_{0.52} \mathrm{Bi}_{0.47} \mathrm{Ti}_{0.99} \mathrm{Ga}_{0.01} \mathrm{O}_{3-\delta} \quad(x=0.01)$ sample is higher, which further leads to the higher total conductivity. 


\subsection{Internal friction spectroscopy}

The temperature dependence of IF $\left(\mathrm{Q}^{-1}\right)$ for $\mathrm{Na}_{0.52} \mathrm{Bi}_{0.47} \mathrm{Ga}_{0.015} \mathrm{Ti}_{0.985} \mathrm{O}_{3-\delta}$ sample at two frequency of $2 \mathrm{~Hz}$ and $4 \mathrm{~Hz}$ is exhibited in Fig.6 [13,15]. Within the test temperature range, three obvious IF peaks (entitled by $\mathrm{P}_{1}$ around $343 \mathrm{~K}, \mathrm{P}_{2}$ around $543 \mathrm{~K}$ and $\mathrm{P}_{3}$ around $785 \mathrm{~K}$ for $2 \mathrm{~Hz}$ ) can be observed. As the test frequency increases, the peak position of $\mathrm{P}_{1}$ peak shifts to the higher temperature, which suggests that $\mathrm{P}_{1}$ peak has typical thermal activation relaxation characteristics[13,20]. For $P_{2}$ and $P_{3}$ peaks, the peak positions hardly move when the test frequency changes, which is the representative phase transition peak characteristic. Based on the reported research results, the $\mathrm{P}_{2}$ and $\mathrm{P}_{3}$ peak may result from the transition process, which correspond to the rhombohedral to orthorhombic phase and the orthorhombic to tetragonal phase, respectively[15,21].

Figure 7 presents the $P_{1}$ peak curve and non-linear fitting result of $\mathrm{Na}_{0.52} \mathrm{Bi}_{0.47} \mathrm{Ti}_{0.985} \mathrm{Ga}_{0.015} \mathrm{O}_{3-\delta}$ sample[15]. For the thermally activated relaxation process, the relation between the relaxation time $\tau$ and activation energy $E$ can be expressed by Arrhenius law: $\tau=\tau_{0} \exp \left(E / K_{B} T\right)[13,20]$. By changing the tested frequency measurement, the relaxation parameters $E$ and the relaxation time $\tau$ can be got: $E=0.78 \mathrm{eV}$ for the $\mathrm{Na}_{0.52} \mathrm{Bi}_{0.47} \mathrm{TiO}_{3-\delta}$ sample[13]. It is easy to find that the activation energies of the $\mathrm{Ga}^{3+}$ doped $\mathrm{Na}_{0.52} \mathrm{Bi}_{0.47} \mathrm{Ti}_{1-\mathrm{x}} \mathrm{Ga}_{\mathrm{x}} \mathrm{O}_{3-\delta}(\mathrm{x}=0.01,0.015,0.02)$ samples range from $0.83 \mathrm{eV}$ to $0.86 \mathrm{eV}$, which is higher than that of $\mathrm{Na}_{0.52} \mathrm{Bi}_{0.47} \mathrm{TiO}_{3-\delta}$ sample, possibly indicating that $\mathrm{Ga}^{3+}$ doping is not beneficial to oxygen ion diffusion.

In order to furter study the influence of $\mathrm{Ga}^{3+}$ inrooduced into NBT based oxygen ion conductor on oxygen ion diffusion, the IF curves of the $\mathrm{Na}_{0.52} \mathrm{Bi}_{0.47} \mathrm{Ga}_{\mathrm{x}} \mathrm{Ti}_{1-\mathrm{x}} \mathrm{O}_{3-\delta}$ $(\mathrm{x}=0,0.01,0.015,0.02)$ samples measured at $4 \mathrm{~Hz}$ with different $\mathrm{Ga}^{3+}$ doping concentration were shown in Fig.8. The internal friction peaks of all samples around $350 \mathrm{~K}$ are observed from Fig.8. Although the IF peak positions are almost unchanged, the IF peak height decrease with the increase of $\mathrm{Ga}^{3+}$ doping concentration, which can be found in the inset of figure 8 .

\section{Discussion}

Through bismuth-defificient and $\mathrm{Na} / \mathrm{Ga}$ acceptor doping methods, oxygen 
vacancy can be introduced into NBT-based compounds just like the following Kroger-Vink equations[3,13]:

$$
\begin{gathered}
2 B i_{B i}^{x}+3 O_{O}^{x} \rightarrow 2 V_{B i}^{\prime \prime \prime}+3 V_{O}^{\bullet \bullet}+B i_{2} O_{3} \\
N a_{2} O \stackrel{B_{2} O_{3}}{\longrightarrow} 2 N a_{B i}^{\prime \prime}+2 V_{O}^{\bullet}+O_{O} \\
G a_{2} O_{3}+2 T i_{T i}^{x}+2 O_{O}^{x} \rightarrow 2 G a_{T i}^{\prime}+V_{O}^{\bullet \bullet}+2 T i O_{2}
\end{gathered}
$$

According to the principle of electric neutrality, there are $3.5 \mathrm{~mol} \%$ nominal oxygen vacancy can be led into the $\mathrm{Na}_{0.52} \mathrm{Bi}_{0.47} \mathrm{TiO}_{3-\delta}$ sample, which results from $\mathrm{Bi}^{3+}$ defect and $\mathrm{Na}^{+}$acceptor doping. Additionly, there are more $0.5 \mathrm{~mol} \%$ oxygen vacancies introduced into the $\mathrm{Na}_{0.52} \mathrm{Bi}_{0.47} \mathrm{Ti}_{0.99} \mathrm{Ga}_{0.01} \mathrm{O}_{3-\delta}$ compounds when the $\mathrm{Ga}$ doped content is $1 \mathrm{~mol} \%$, suggesting that oxygen vacancy concentration can be increased due to introduce $\mathrm{Ga}^{3+}$ into the $\mathrm{Na}_{0.52} \mathrm{Bi}_{0.47} \mathrm{Ti}_{1-\mathrm{x}} \mathrm{Ga}_{\mathrm{x}} \mathrm{O}_{3-\delta}$ samples .

According to the reported results[12], not all oxygen vacancies are involved in the diffusion migration of oxygen ions and there are immobile oxygen vacancies in the oxygen conductor. Normally, the mobile oxygen vacancies are of great significance to the electrical properties of oxygen-ion conductors[3]. Based on the point defect relaxation theory, the height of the relaxation peak have a linear relationship with the mobile vacancy concentration[13]. The inset of figure 8 gives the peaks height of $\mathrm{P}_{1}$ peaks for the $\mathrm{Na}_{0.52} \mathrm{Bi}_{0.47} \mathrm{Ti}_{1-\mathrm{x}} \mathrm{Ga}_{\mathrm{x}} \mathrm{O}_{3-\delta}(\mathrm{x}=0,0.01,0.015,0.02)$ compounds dependent the $\mathrm{Ga}^{3+}$ doping content. Obviously, the height of the $\mathrm{P}_{1}$ peaks for $\mathrm{Na}_{0.52} \mathrm{Bi}_{0.47} \mathrm{Ti}_{1-\mathrm{x}} \mathrm{Ga}_{\mathrm{x}} \mathrm{O}_{3-\delta}$ compounds decrease with the increase of the $\mathrm{Ga}^{3+}$ doping concentration. Namely, the mobile oxygen vacancy concentration decrease with the introduction of the $\mathrm{Ga}^{3+}$ into the $\mathrm{Na}_{0.52} \mathrm{Bi}_{0.47} \mathrm{Ti}_{1-\mathrm{x}} \mathrm{Ga}_{\mathrm{x}} \mathrm{O}_{3-\delta}$ samples. In $\mathrm{Na}_{0.52} \mathrm{Bi}_{0.47} \mathrm{Ti}_{1-\mathrm{x}} \mathrm{Ga}_{\mathrm{x}} \mathrm{O}_{3-\delta}$ compounds, due to electrostatic attraction, there is a capture effect between oxygen vacancy and B-site acceptor ion such as $\mathrm{Ga}^{3+}$, which leads to the formation of defect pairs such as $\left(G a_{T i}^{\prime}-V_{O}^{\bullet \bullet}-G a_{T i}^{\prime}\right)^{\times}$and $\left(G a_{\mathrm{Ti}}^{\prime}-V_{O}^{\bullet \bullet}\right)^{\bullet}$. The decline in mobile oxygen vacancy content as a direct consequence of the formation of defect pairs[1-2].

For the perovskite structural oxygen ion conductors, oxygen ion migration mainly passes through the Na-Bi-Ti saddle point as a rate-limiting step[7]. When $\mathrm{Ga}^{3+}$ ions 
are introduced into the $\mathrm{Na}_{0.52} \mathrm{Bi}_{0.47} \mathrm{TiO}_{3-\delta}$ compound, the polarizability of the donor ions $\left(\alpha_{\mathrm{Ga}}=1.50 \AA^{3}\right)$ is lower than that of the substituted ion $\left(\alpha_{\mathrm{Ti}}=2.93 \AA^{3}\right)$, which is unfavourable for oxygen vacancy transport [2]. The increase of the oxygen relaxation activation energy educed from the IF measurement also proves that $\mathrm{Ga}^{3+}$ doping is not binifical to oxygen ion diffusion in the NBT-based oxygen-ion conductors.

\section{Conclusion}

$\mathrm{Na}_{0.52} \mathrm{Bi}_{0.47} \mathrm{Ti}_{1-\mathrm{x}} \mathrm{Ga}_{\mathrm{x}} \mathrm{O}_{3-\delta}(\mathrm{x}=0,0.01,0.015,0.02)$ samples with single perovskite phase were fabricated by the way of conventional solid-state reaction. Through the AC impedance test, a slight of $\mathrm{Ga}^{3+}$ doping can decrease the grain-boundary resistivity and increase the total ionic conductivity. The highest total conductivity emerges in the $\mathrm{Na}_{0.52} \mathrm{Bi}_{0.47} \mathrm{Ti}_{0.99} \mathrm{Ga}_{0.01} \mathrm{O}_{3-\delta}$ sample with the $\mathrm{Ga}^{3+}$ doping content of 1 mol\%, which is $1.387 \times 10^{-4} \mathrm{~S} / \mathrm{cm}$ at $623 \mathrm{~K}$. The bulk conductivity of $\mathrm{Na}_{0.52} \mathrm{Bi}_{0.47} \mathrm{Ti}_{1-\mathrm{x}} \mathrm{Ga}_{\mathrm{x}} \mathrm{O}_{3-\delta}$ samples exhibit a monotonous reduction. The bulk conductivity of $\mathrm{Na}_{0.52} \mathrm{Bi}_{0.47} \mathrm{Ti}_{0.99} \mathrm{Ga}_{0.01} \mathrm{O}_{3-\delta}(\mathrm{x}=0,0.01,0.015,0.02)$ reaches $1.01 \times 10^{-3}$ $\mathrm{S} / \mathrm{cm}$ at $673 \mathrm{~K}$ declined to $7.19 \times 10^{-4} \mathrm{~S} / \mathrm{cm}$ for the $\mathrm{Na}_{0.52} \mathrm{Bi}_{0.47} \mathrm{Ti}_{0.98} \mathrm{Ga}_{0.02} \mathrm{O}_{3-\delta}$ sample. Through the internal friction measurement at different frequencies, there is an increase trend of the oxygen ion relaxation activation energy along with the introduction of the $\mathrm{Ga}^{3+}$, meanwhile, the mobile oxygen vacancies concentration decrease owing to the formation of local defect clusters, which is the possible reason that the bulk conductivity of $\mathrm{Na}_{0.52} \mathrm{Bi}_{0.47} \mathrm{Ti}_{1-\mathrm{x}} \mathrm{Ga}_{\mathrm{x}} \mathrm{O}_{3-\delta}(\mathrm{x}=0,0.01,0.015,0.02)$ samples reduce with the $\mathrm{Ga}^{3+}$ doping concentration.

\section{Acknowledgments}

This work has been subsidized by the National Natural Science Foundation of China (No. 12064044, 11604286).

\section{Reference}

1. R. Bhattacharyya, S. Omar, Electrical conductivity study of Ga doped non-stoichiometric sodium bismuth titanate ceramics. J. Alloy. Compd. 746, 54-61 (2018)

2. X. M. Xu, X. Liu, R. R. Rao, Y. X. Zhao, H. Du, J. Shi, Electrical properties and conduction mechanisms of $\mathrm{K}, \mathrm{Ga}$ co-substituted $\mathrm{Na}_{0.5} \mathrm{Bi}_{0.5} \mathrm{TiO}_{3}$ ferroelectrics. Ceramics. 46(14), 2772-8842 (2020) 
3. W. G. Wang, M. Y. Li, X. Y. Li, G. L. Hao, The investigation on the Sr, Mg codoped $\mathrm{Na}_{0.5} \mathrm{Bi}_{0.5} \mathrm{TiO}_{3}$ oxide ion conductor prepared by spark plasma sintering. Ionics. 25, 4265-4271 (2019)

4. W. G. Wang, M. Y. Li, T. Liu, X. F. Wang, D. Wang, G. L. Hao, The effect of A-site sublattice order on the electrical properties of $\mathrm{Na}_{0.5} \mathrm{Bi}_{0.5} \mathrm{TiO}_{3}$ compound. J. Mater. Sci.: Mater. Electron. 30(16), 15139-15144 (2019)

5. H. Yahiro, T. Ohuchi, K. Eguchi, Electrical properties and microstructure in the system ceria-alkaline earth oxide. Journal of Materials Science. J. Mater. Sci. 23, 1036-1041 (1988)

6. M. Li, M. J. Pietrowski, R. A. De Souza, H. Zhang, I. M. Reaney, S. N. Cook, J. A. Sinclair, A family of oxide ion conductors based on the ferroelectric perovskite $\mathrm{Na}_{0.5} \mathrm{Bi}_{0.5} \mathrm{TiO}_{3}$. Nat. Mater. 13, 31-35 (2014)

7. F. Yang, P. Wu, D. C. Sinclair, Enhanced bulk conductivity of A-site divalent acceptor-dpoed non-stoichiometric sodium bismuth titanate. Solid State Ionics 299, 38-45(2017)

8. J. Q. Huang, F. Y. Zhu, D. Huang, B. Wang et al., Intermediate-temperature conductivity of B-site doped $\mathrm{Na}_{0.5} \mathrm{Bi}_{0.5} \mathrm{TiO}_{3}$-based lead-free ferroelectric ceramics. Ceram. Int. 42, 16798-16803(2016)

9. R. Bhattacharyya, S. Das, A.Das, S. Omar et al., Effect of sintering temperature on the microstructure and conductivity of $\mathrm{Na}_{0.54} \mathrm{Bi}_{0.46} \mathrm{Ti}_{0.99} \mathrm{Mg}_{0.01} \mathrm{O}_{3-\delta}$. Solid State Ionics, 360, 115547(2021)

10. F. Yang, J. S. Dean, Q. Hu, P. Wu et al., From insulator to oxide-ion conductor by a synergistic effect from defect chemistry and microstructure: acceptor-doped Bi-excess sodium bismuth titanate $\mathrm{Na}_{0.5} \mathrm{Bi}_{0.51} \mathrm{TiO}_{3.015}$. J. Mater. Chem A 8(2020)

11. R. Bhattacharyya, S. Omar, Influence of excess sodium addition on the structural characteristics and electrical conductivity of $\mathrm{Na}_{0.5} \mathrm{Bi}_{0.5} \mathrm{TiO}_{3}$. Solid State Ionics 317, 115-121(2018)

12. W. G. Wang, X. Y. Li, T. Liu, G. L. Hao, Mechanical and dielectric relaxation studies on the fast oxide ion conductor $\mathrm{Na}_{0.54} \mathrm{Bi}_{0.46} \mathrm{TiO}_{2.96}$. Solid State Ionics 290, 6-11(2016)

13. W. G. Wang, Study on the electrical conductivity and relaxation behavior of K-doped $\mathrm{Na}_{0.5} \mathrm{Bi}_{0.5} \mathrm{TiO}_{3}$ ceramics. J. Mater. Sci.: Mater. Electron. 29, 3973-3979(2019)

14. F. Yang., H. Zhang., L. Lin, I. M. Reaney, D. C. Sinclair, High ionic conductivity with low degradation in A-site strontium doped non-stoichiometric sodium bismuth titanate perovskite. Chem. Mater. 28, 5269-5273 (2016)

15. W. G. Wang, X. Y. Li, T. Liu, G. L. Hao, Study on electrical Conductivity and oxygen migration of theoxide-ion conductors $\mathrm{Na}_{0.5} \mathrm{Bi}_{0.5} \mathrm{Ti}_{1-\mathrm{x}} \mathrm{Mg}_{\mathrm{x}} \mathrm{O}_{3-\mathrm{x}}$. B. Mater. Sci. 42, 1-8(2019)

16. D. P. Almond, A.R. West, Impedance and modulus spectroscopy of "real" dispersive conductors. Solid State Ionics 11, 57-64 (1983)

17. F. Yang, P. Wu, D. C. Sinclair, Suppression of electric conductivity and switching of conduction mechanisms in 'stoichiometric' $\left(\mathrm{Na}_{0.5} \mathrm{Bi}_{0.5} \mathrm{TiO}_{3}\right)_{1-\mathrm{x}}\left(\mathrm{BiAlO}_{3}\right)_{\mathrm{x}}(0 \leq \mathrm{x} \leq 0.08)$ solid solutions. J. Mater. Chem. C 5, 7243-7252(2017)

18. W. G. Wang, X. Y. Li, T. Liu, G. L. Hao, Influence of A-site Off-stoichiomety on grain conductivity and oxygen relaxation behavior of $\mathrm{Na}_{0.5} \mathrm{Bi}_{0.5} \mathrm{TiO}_{3}$ ceramics. Solid State Ionics 327, 117-122(2018)

19. W. G. Wang, X. P. Wang, Y. X. Gao, Q. F. Fang, Lithium-ionic diffusion and electric conduction in the $\mathrm{Li}_{7} \mathrm{La}_{3} \mathrm{Ta}_{2} \mathrm{O}_{13}$ compounds. Solid State Ionics 180, 1252-1256(2009) 
20. W. G. Wang, X. P. Wang, C. Li, Y. L. Li, Q. F. Fang, Damping properties of $\mathrm{Li}_{5} \mathrm{La}_{3} \mathrm{Ta}_{2} \mathrm{O}_{12}$ particles reinforced aluminum matrix composites. Mater. Sci. Eng. A 518, 190-193(2009)

21. Y. Z. Liu, G. P. Zheng, Anelastic analyses on the relaxation of anti-ferroelectric states in $0.94 \mathrm{Na}_{0.5} \mathrm{Bii}_{0.5} \mathrm{TiO}_{3}-0.06 \mathrm{BaTiO}_{3}$ solid solutions under electric fields. J. Electroceram. 34(1), 38-42(2015)

22. X. P. Wang, F. Fang, Mechanical and dielectric relaxation studies on the mechanism of oxygen ion diffusion in $\mathrm{La}_{2} \mathrm{Mo}_{2} \mathrm{O}_{9}$. Phys. Rev. B 65(6), 064304(2002)

Table 1 AC impedance spectra and fitting results of $\mathrm{Na}_{0.52} \mathrm{Bi}_{0.47} \mathrm{Ti}_{1-\mathrm{x}} \mathrm{Ga}_{\mathrm{x}} \mathrm{O}_{3-\delta}(\mathrm{x}=0$, $0.01,0.015,0.02)$ samples

\begin{tabular}{ccccccc}
\hline sample & $\mathrm{R}_{\mathrm{b}}(\Omega)$ & $\mathrm{C}_{\mathrm{b}}(\mathrm{F})$ & $\mathrm{R}_{\mathrm{gb}}(\Omega)$ & $\mathrm{C}_{\mathrm{gb}}(\mathrm{F})$ & $\mathrm{R}_{\mathrm{el}}(\Omega)$ & $\mathrm{C}_{\mathrm{el}}(\mathrm{F})$ \\
\hline $\mathrm{Na} 0.52 \mathrm{Bi}_{0.47} \mathrm{TiO}_{3-\delta}$ & 416 & $2.68810^{-10}$ & 2111 & $1.67 \times 10^{-7}$ & 7702 & $5.75 \times 10^{-6}$ \\
$\mathrm{Na}_{0.52} \mathrm{Bi}_{0.47} \mathrm{Ga}_{0.01} \mathrm{Ti}_{0.99} \mathrm{O}_{3-\delta}$ & 409 & $2.77 \times 10^{-10}$ & 827.5 & $1.17 \times 10^{-7}$ & 4288 & $6.27 \times 10^{-6}$ \\
$\mathrm{Na}_{0.52} \mathrm{Bi}_{0.47} \mathrm{Ga}_{0.015} \mathrm{Ti}_{0.985} \mathrm{O}_{3-\delta}$ & 541 & $3.16 \times 10^{-10}$ & 1986 & $2.93 \times 10^{-7}$ & 3106 & $1.77 \times 10^{-5}$ \\
$\mathrm{Na}_{0.52} \mathrm{Bi}_{0.47} \mathrm{Ga}_{0.02} \mathrm{Ti}_{0.98} \mathrm{O}_{3-\delta}$ & 627 & $4.18 \times 10^{-10}$ & 1122 & $9.38 \times 10^{-8}$ & 1617 & $3.95 \times 10^{-5}$ \\
\hline
\end{tabular}




\section{Figure Captions}

Fig.1 Room temperature XRD patterns for the $\mathrm{Na}_{0.5} \mathrm{Bi}_{0.5} \mathrm{TiO}_{3}$ and $\mathrm{Na}_{0.52} \mathrm{Bi}_{0.47} \mathrm{Ti}_{1-\mathrm{x}} \mathrm{Ga}_{\mathrm{x}} \mathrm{O}_{3-\delta}(\mathrm{x}=0,0.01,0.015,0.02)$ samples.

Fig.2 The AC impedance plots of the $\mathrm{Na}_{0.52} \mathrm{Bi}_{0.47} \mathrm{Ti}_{1-\mathrm{x}} \mathrm{Ga}_{\mathrm{x}} \mathrm{O}_{3-\delta} \quad(\mathrm{x}=0,0.01$, $0.015)$ samples samples at $643 \mathrm{~K}$.

Fig. 3 The Arrhenius plots of bulk conductivity for the $\mathrm{Na}_{0.52} \mathrm{Bi}_{0.47} \mathrm{Ti}_{1-\mathrm{x}} \mathrm{Ga}_{\mathrm{x}} \mathrm{O}_{3-\delta}(\mathrm{x}=0$, $0.01,0.015,0.02)$ samples.

Fig.4 The bulk conductivity of the $\mathrm{Na}_{0.52} \mathrm{Bi}_{0.47} \mathrm{Ga}_{\mathrm{x}} \mathrm{Ti}_{1-\mathrm{x}} \mathrm{O}_{3-\delta}(\mathrm{x}=0,0.01,0.015,0.02)$ samples at the different temperature.

Fig.5 The total conductivity of the $\mathrm{Na}_{0.52} \mathrm{Bi}_{0.47} \mathrm{Ti}_{1-\mathrm{x}} \mathrm{Ga}_{\mathrm{x}} \mathrm{O}_{3-\delta}(\mathrm{x}=0,0.01,0.015,0.02)$ samples at different temperature $(593 \mathrm{~K}, 613 \mathrm{~K}$ and $623 \mathrm{~K})$.

Fig.6 IF $\mathrm{Q}^{-1}$ versus temperature for the $\mathrm{Na}_{0.52} \mathrm{Bi}_{0.47} \mathrm{Ti}_{0.985} \mathrm{Ga}_{0.015} \mathrm{O}_{3-\delta}$ sample measured at different frequencies $(2 \mathrm{~Hz}$ and $4 \mathrm{~Hz})$ in the temperature range from room temperature to $700 \mathrm{~K}$.

Fig.7 IF $\mathrm{Q}^{-1}$ versus temperature for the $\mathrm{Na}_{0.52} \mathrm{Bi}_{0.47} \mathrm{Ti}_{0.985} \mathrm{Ga}_{0.015} \mathrm{O}_{3-\delta}$ sample measured at different frequencies $(1 \mathrm{~Hz}, 2 \mathrm{~Hz}$ and $4 \mathrm{~Hz})$ in the temperature range from $290 \mathrm{~K}$ to $425 \mathrm{~K}$ and non-linear fitting results.

Fig.8 IF $\mathrm{Q}^{-1}$ versus temperature for the $\mathrm{Na}_{0.52} \mathrm{Bi}_{0.47} \mathrm{Ti}_{1-\mathrm{x}} \mathrm{Ga}_{\mathrm{x}} \mathrm{O}_{3-\delta}(\mathrm{x}=0,0.01,0.015)$ samples measured at $4 \mathrm{~Hz}$ in the temperature range from $290 \mathrm{~K}$ to $440 \mathrm{~K}$. The curve of the relaxation time $\tau$ versus $\mathrm{Ga}^{3+}$ doped content is given in the inset. 
Figure 1 by M. Y. Li et al

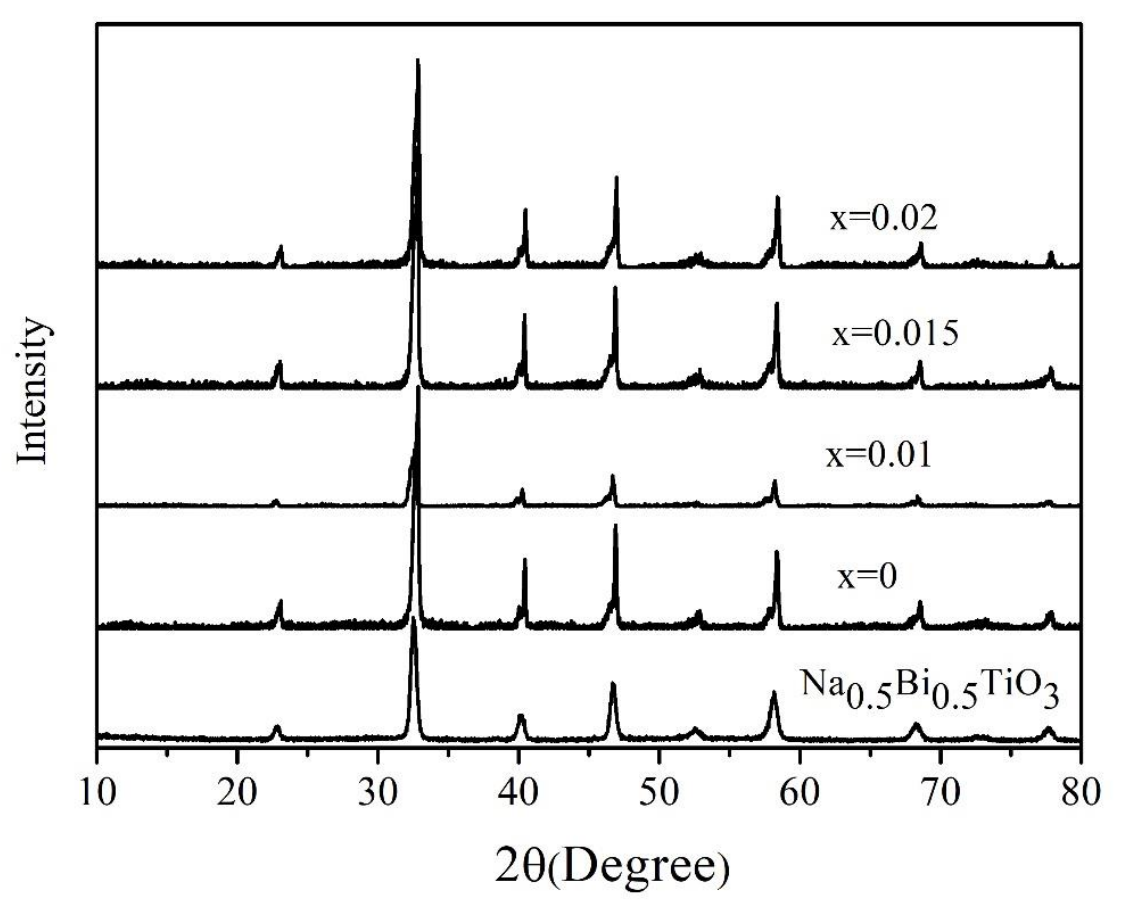


Figure 2 by M. Y. Li et al

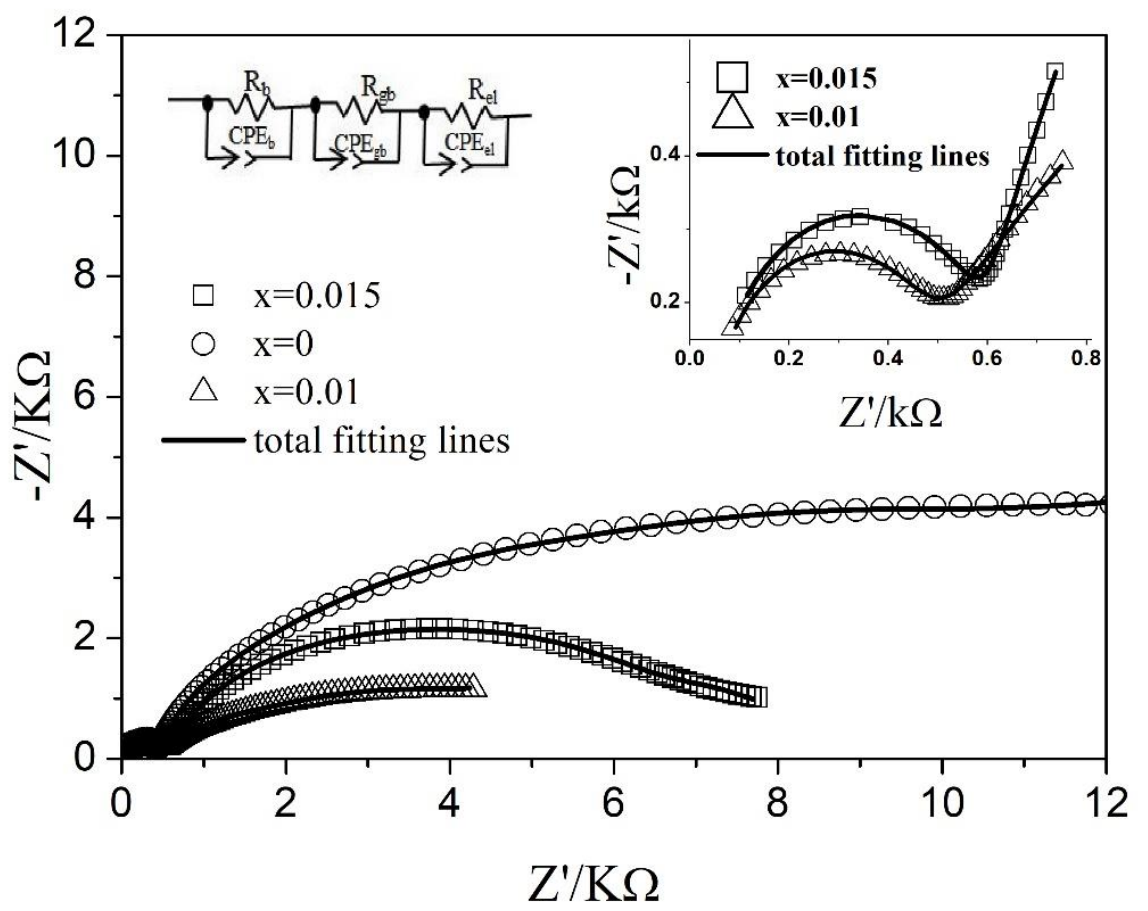


Figure 3by M. Y. Li et al

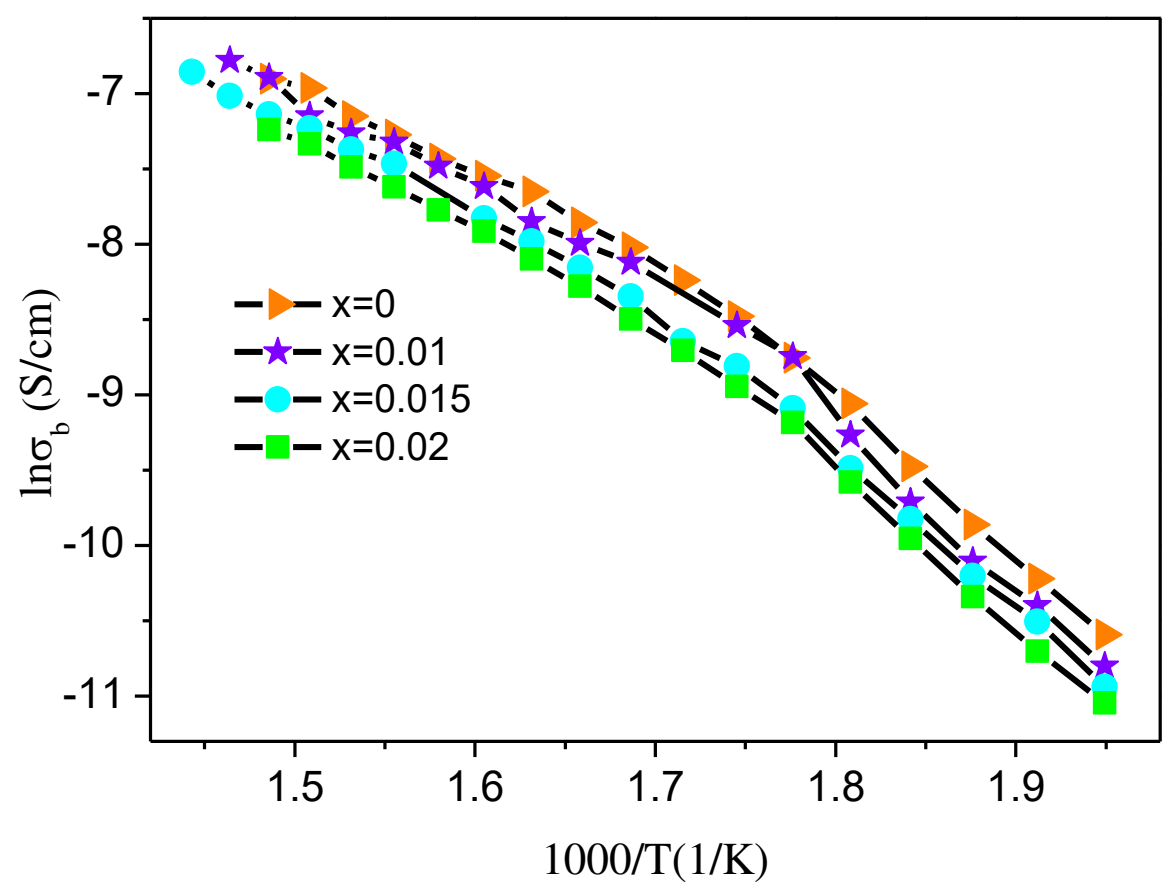


Figure 4 by M. Y. Li et al

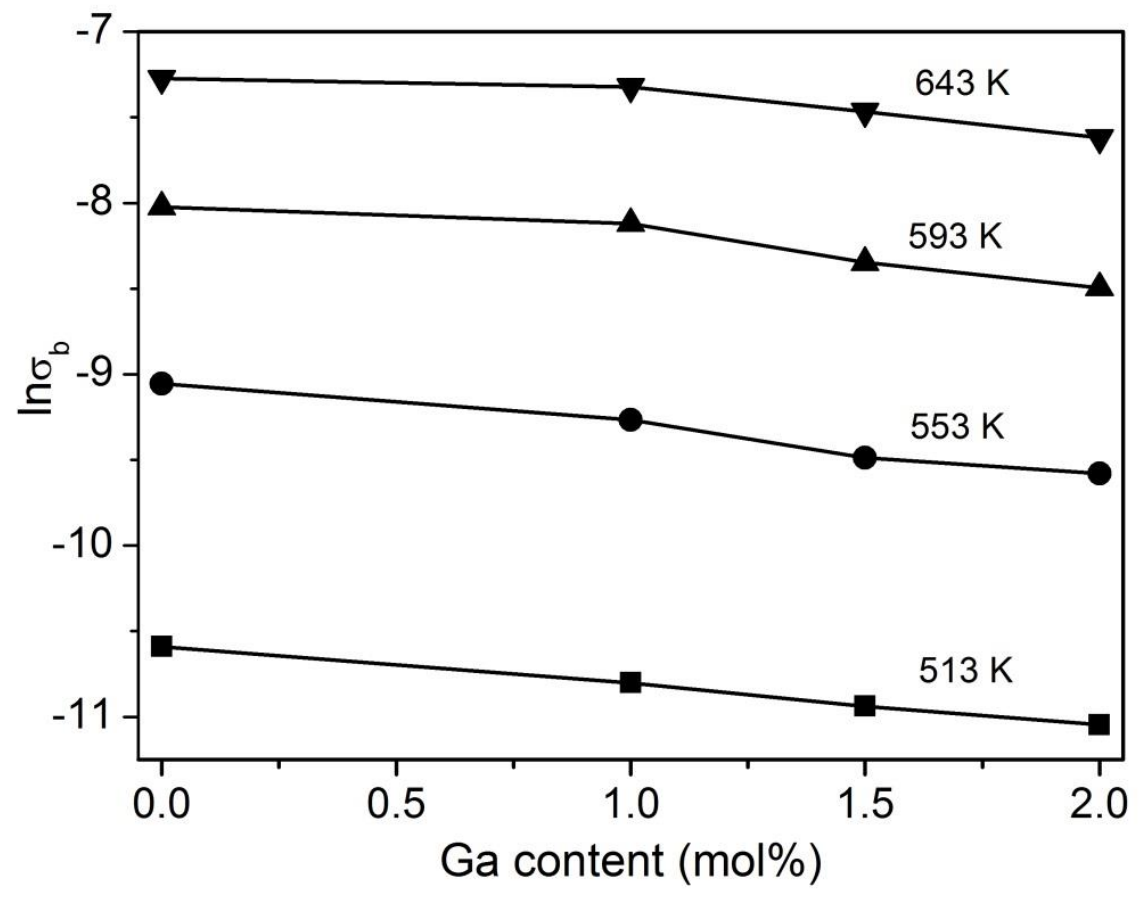


Figure 5 by M. Y. Li et al

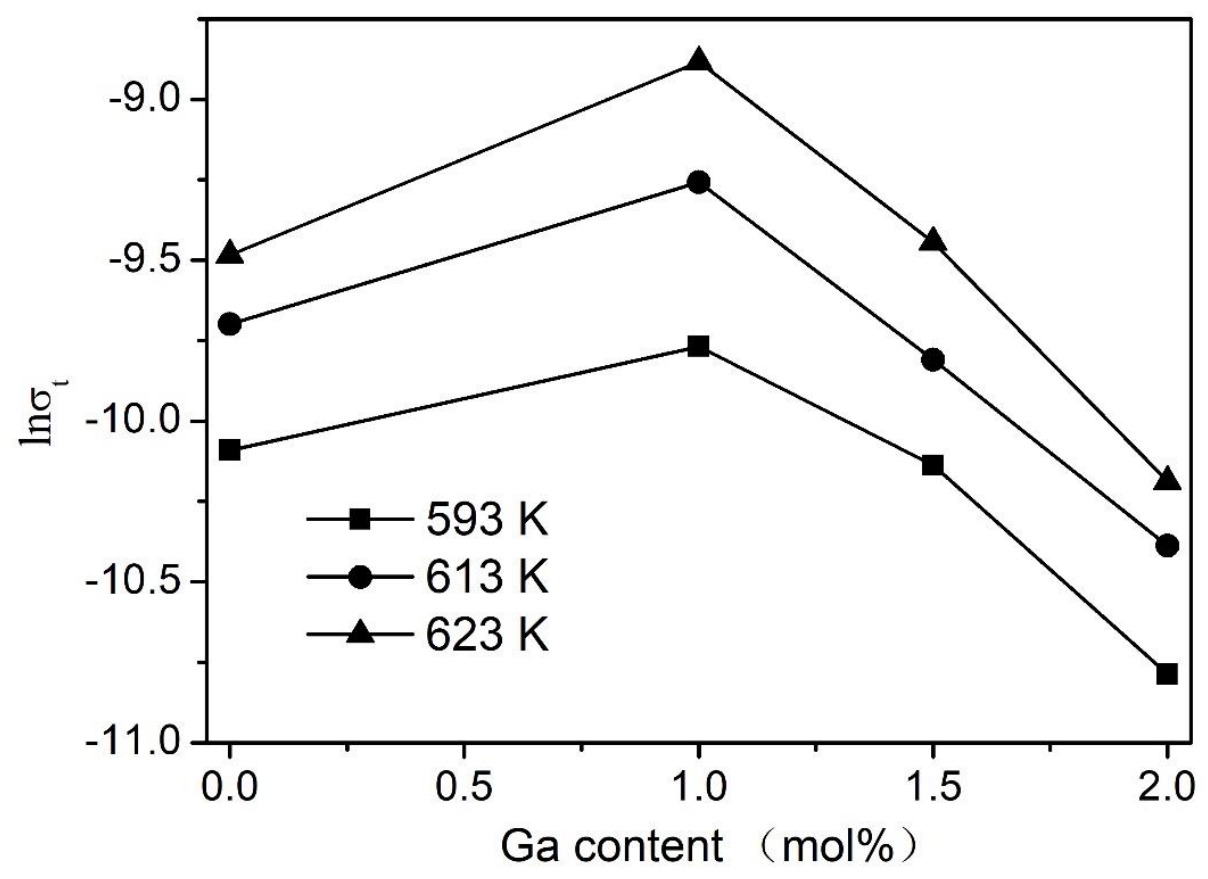


Figure 6 by M. Y. Li et al

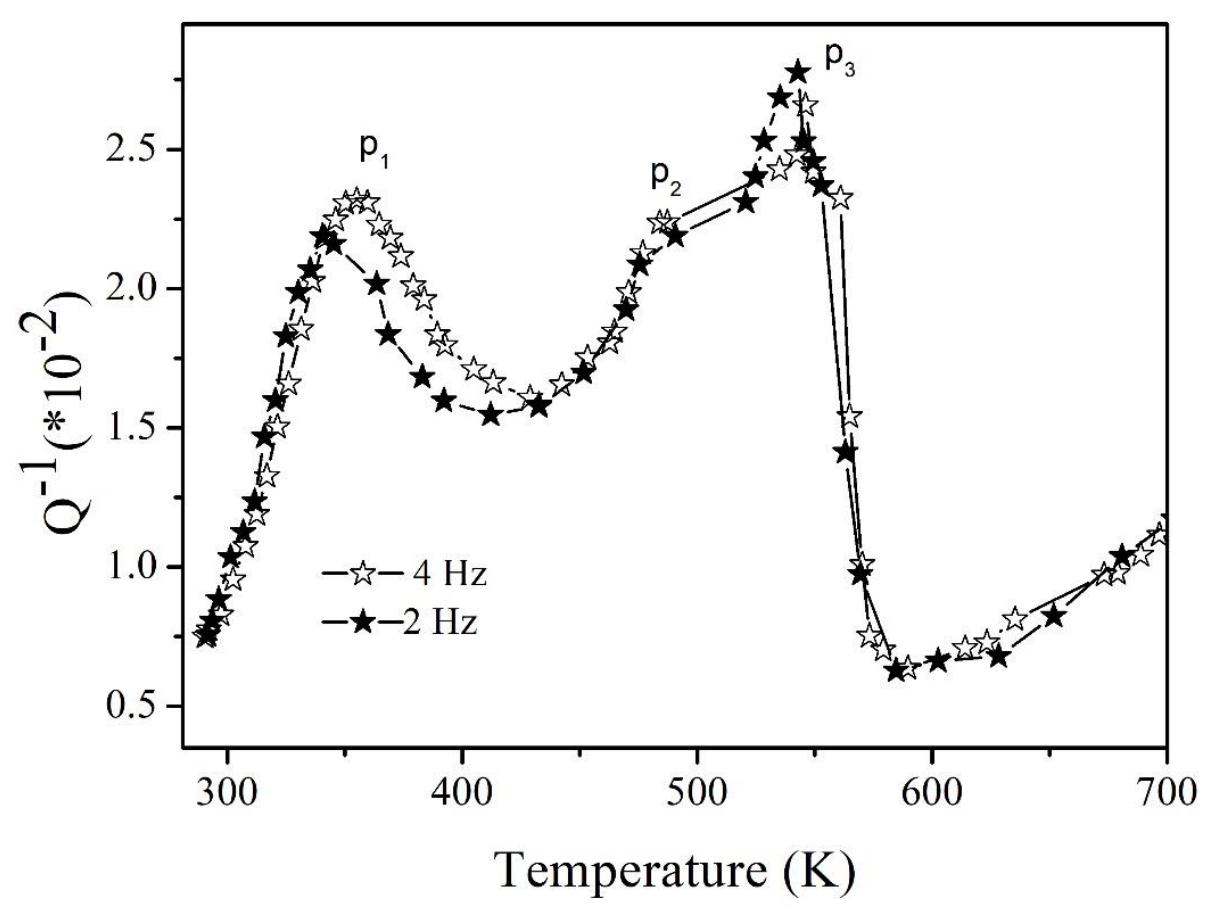


Figure 7 by M. Y. Li et al

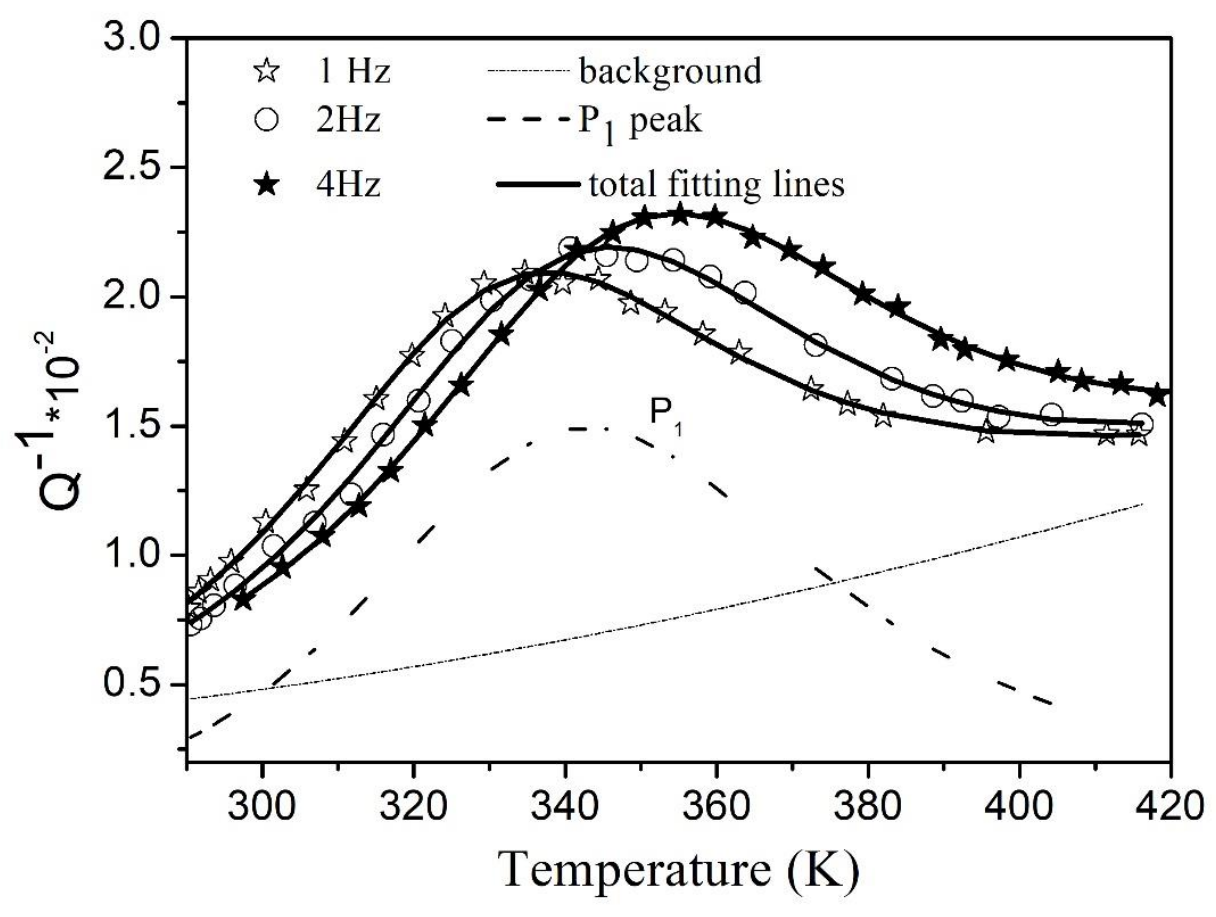


Figure 8 by M. Y. Li et al

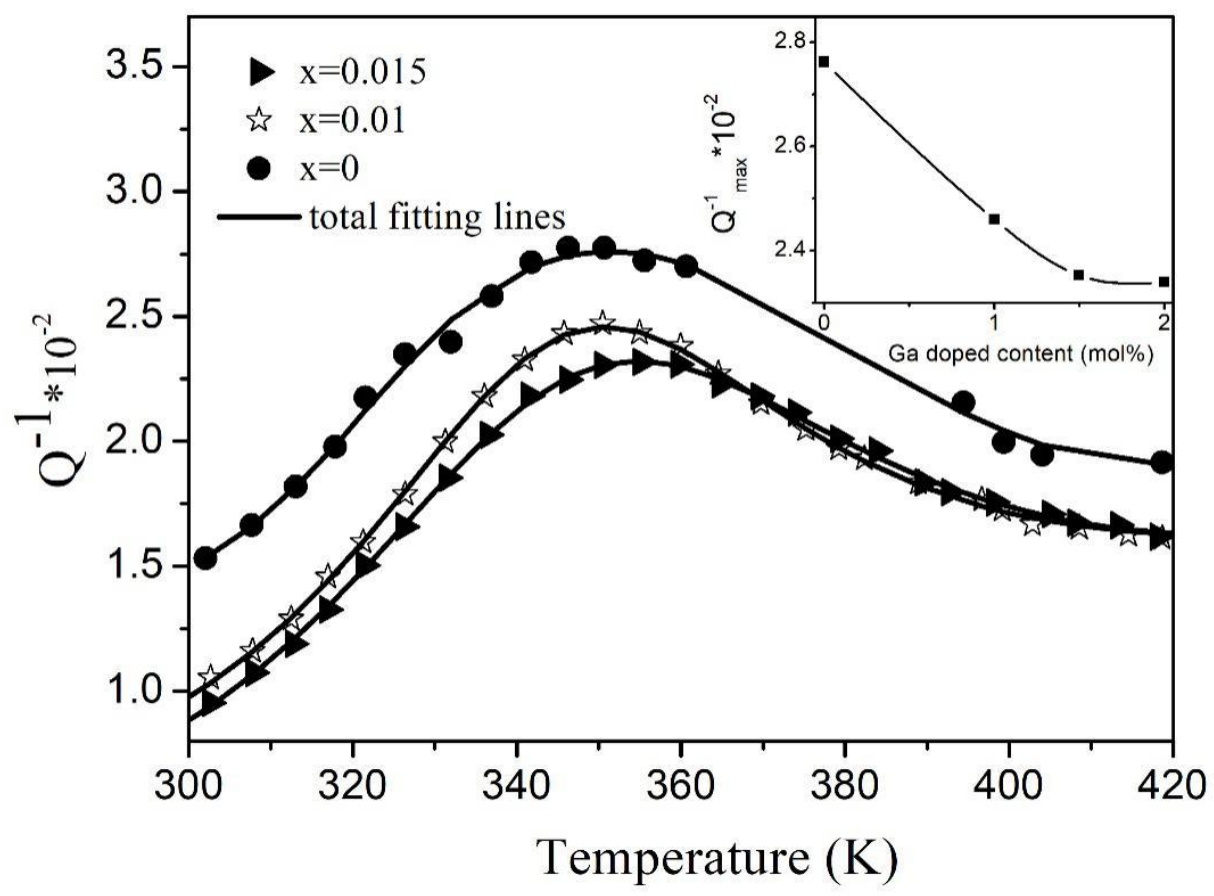


Figures

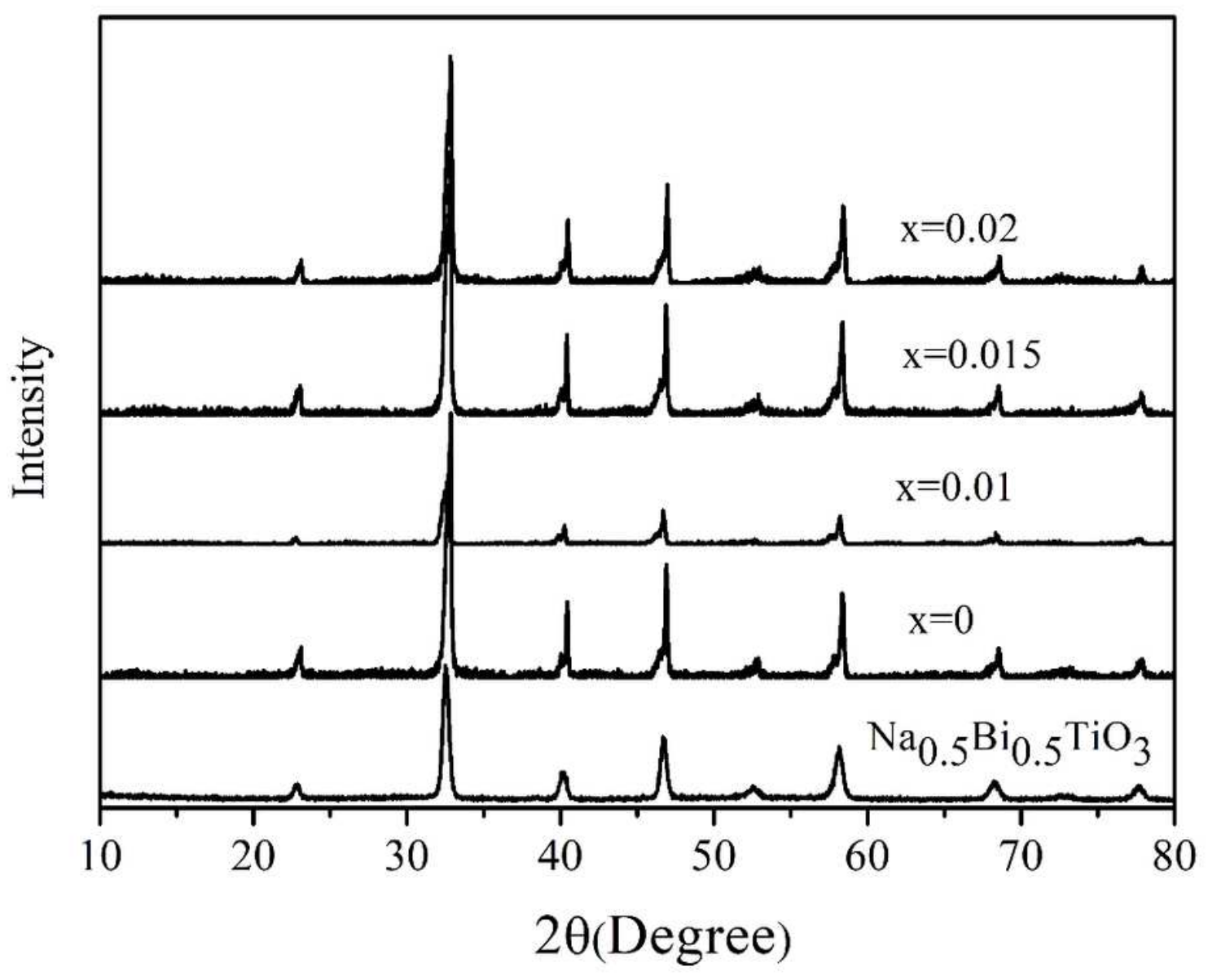

Figure 1

Room temperature XRD patterns for the Na0.5Bi0.5TiO3 and Na0.52Bi0.47Ti1-xGaxO3- $\delta(x=0,0.01$, $0.015,0.02)$ samples. 


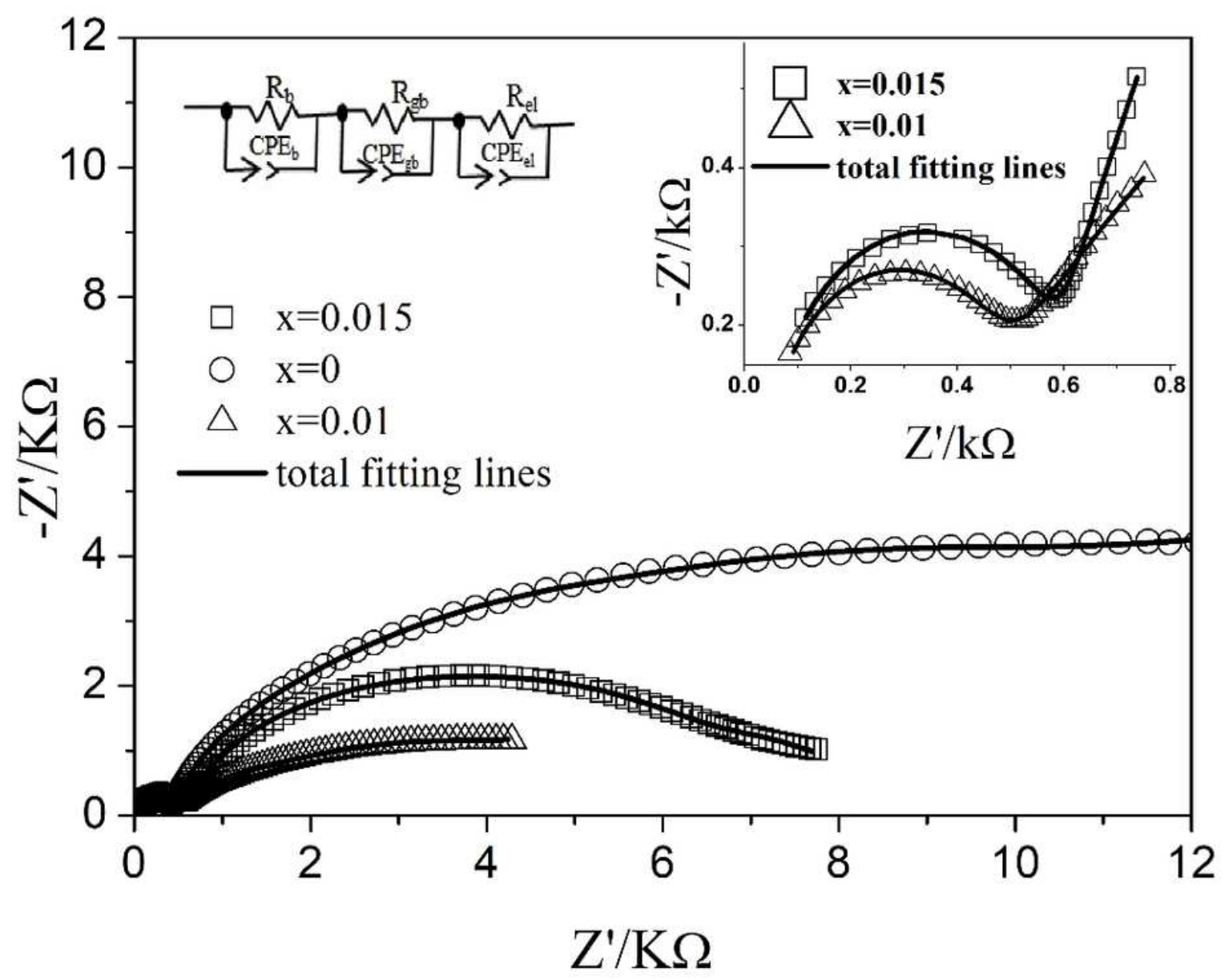

Figure 2

The AC impedance plots of the Na0.52Bi0.47Ti1-xGaxO3- $\delta(x=0,0.01,0.015)$ samples samples at $643 \mathrm{~K}$.

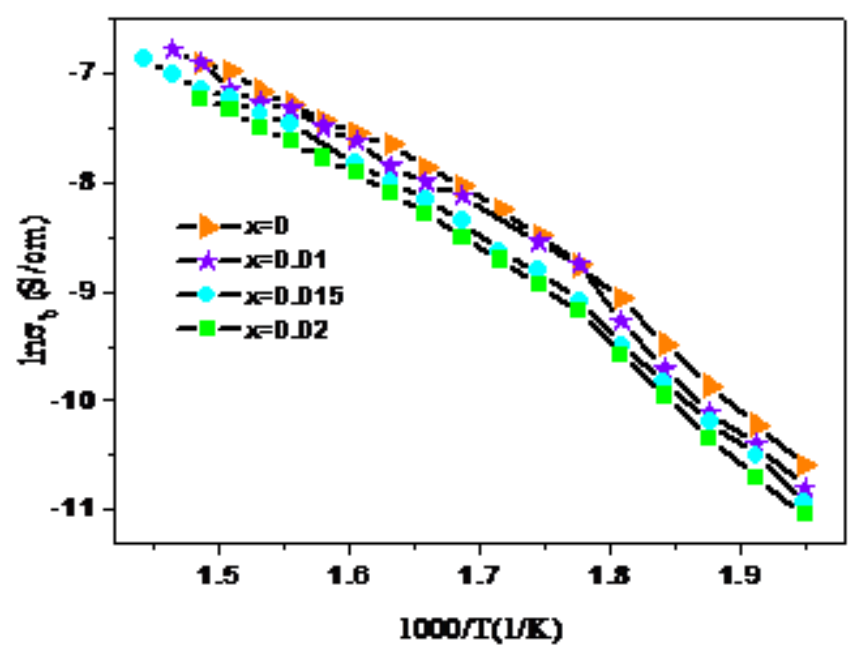

Figure 3 
The Arrhenius plots of bulk conductivity for the Na0.52Bi0.47Ti1-xGaxO3- $\delta(x=0,0.01,0.015,0.02)$ samples.

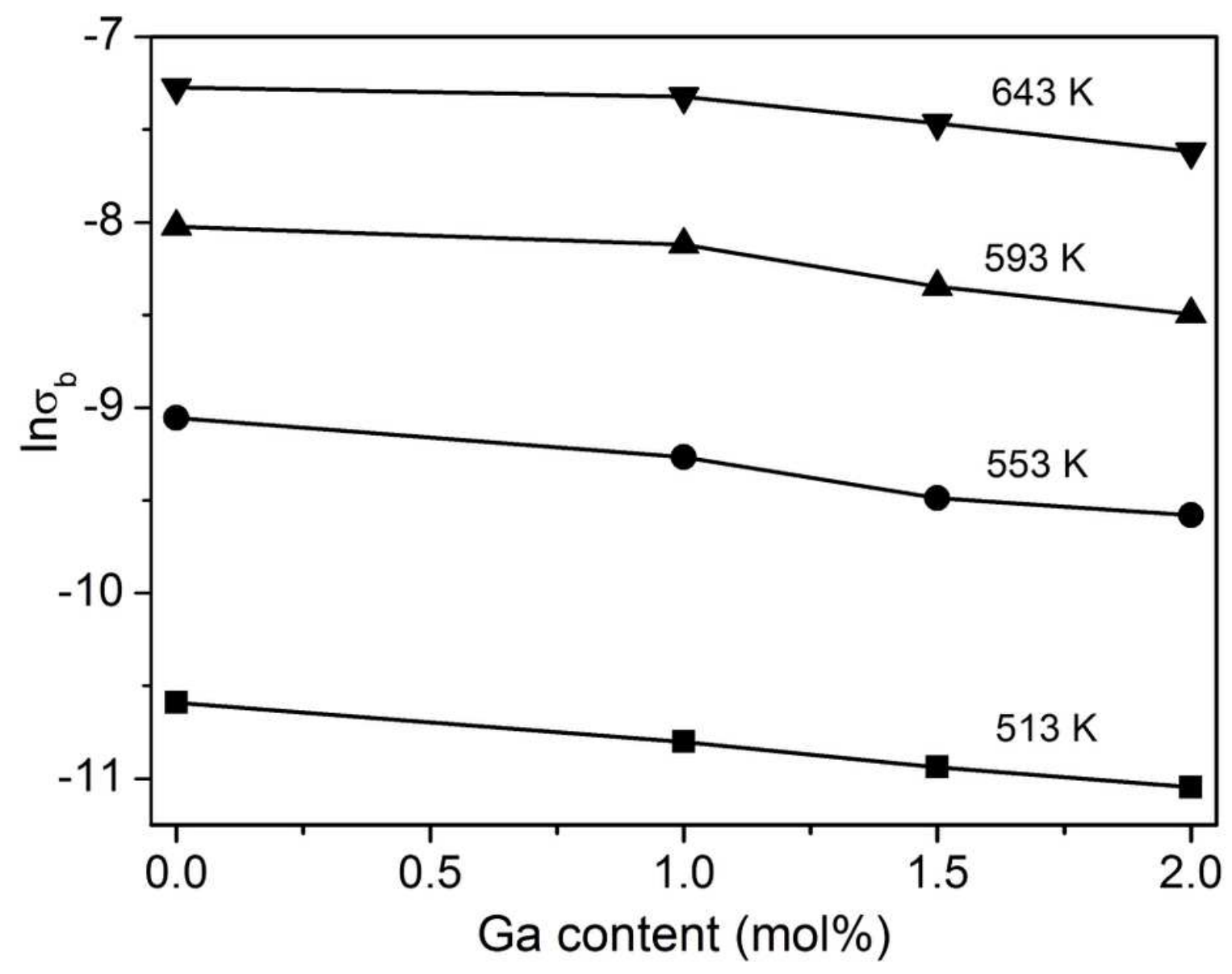

Figure 4

The bulk conductivity of the Na0.52Bi0.47GaxTi1-xO3- $\delta(x=0,0.01,0.015,0.02)$ samples at the different temperature. 




Figure 5

The total conductivity of the Na0.52Bi0.47Ti1-xGaxO3- $\delta(x=0,0.01,0.015,0.02)$ samples at different temperature $(593 \mathrm{~K}, 613 \mathrm{~K}$ and $623 \mathrm{~K})$. 


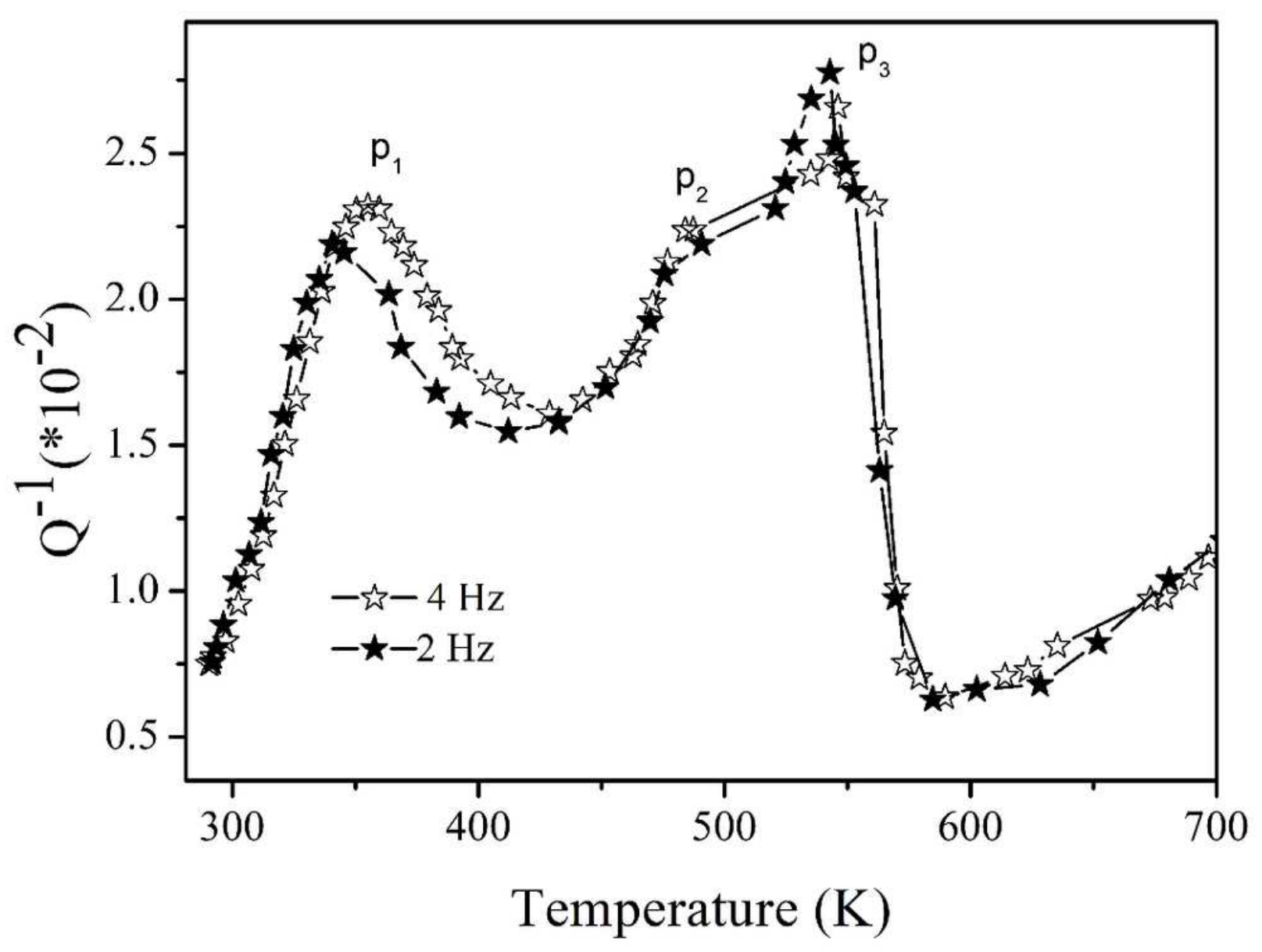

Figure 6

IF Q-1 versus temperature for the $\mathrm{Na} 0.52 \mathrm{Bi} 0.47 \mathrm{Ti} 0.985 \mathrm{Ga} 0.01503-\delta$ sample measured at different frequencies $(2 \mathrm{~Hz}$ and $4 \mathrm{~Hz})$ in the temperature range from room temperature to $700 \mathrm{~K}$. 


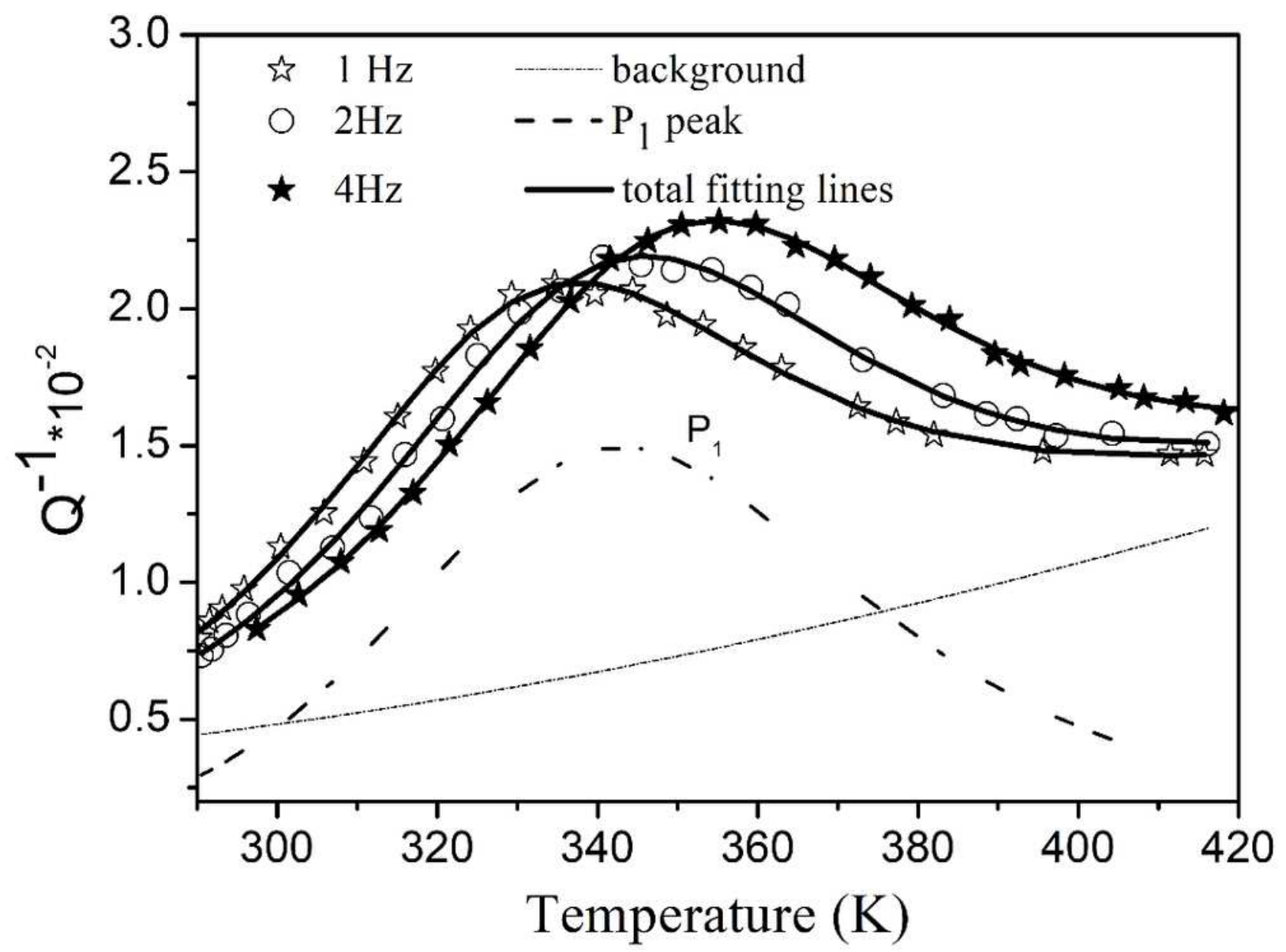

Figure 7

IF Q-1 versus temperature for the Na0.52Bi0.47Ti0.985Ga0.01503- $\delta$ sample measured at different frequencies $(1 \mathrm{~Hz}, 2 \mathrm{~Hz}$ and $4 \mathrm{~Hz}$ ) in the temperature range from $290 \mathrm{~K}$ to $425 \mathrm{~K}$ and non-linear fitting results. 


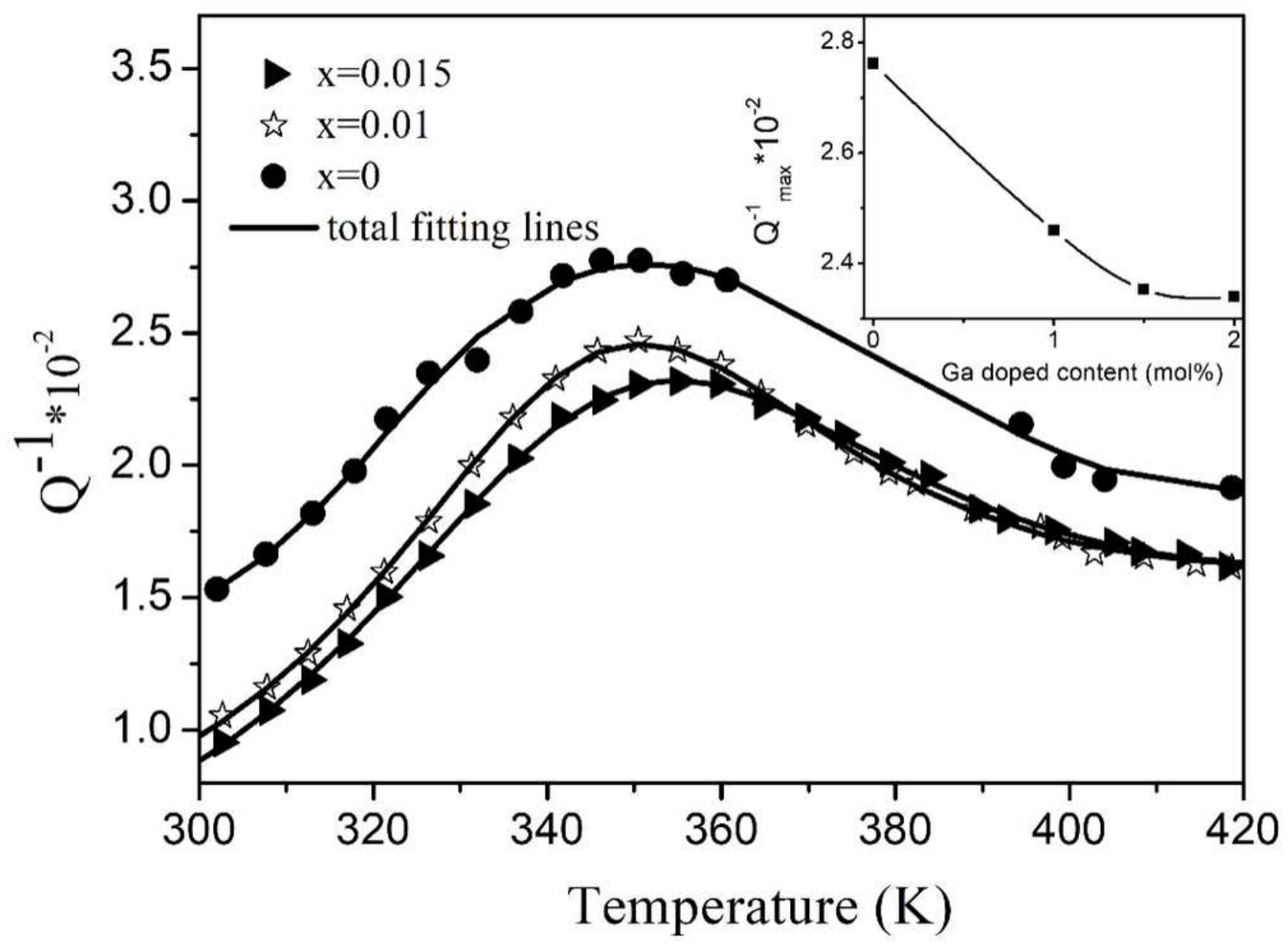

Figure 8

IF Q-1 versus temperature for the Na0.52Bi0.47Ti1-xGaxO3- $\delta(x=0,0.01,0.015)$ samples measured at 4 $\mathrm{Hz}$ in the temperature range from $290 \mathrm{~K}$ to $440 \mathrm{~K}$. The curve of the relaxation time $\tau$ versus $\mathrm{Ga} 3+$ doped content is given in the inset. 